\title{
Проблеми деліберативних практик у Європейському Союзі за Джеймсом Фішкіним
}

\section{Ковальов А. В., Київський національний університет імені Тараса Шевченка}

У статті здійснено спробу комплексного дослідження перспектив деліберативних практик у масштабах Європейського Союзу, а не окремих держав-членів у контексті теорії демократії Джеймса Фішкіна. Доведено, що системне використання деліберативної методології удосконалення демократії в ЄС можливе лише за умови формування спільної публічної сфери, яка зможе стати фундаментом для розробки загальних публічних рішень щодо проблем Європейського Союзу у процесі дорадчих консультувань. Учасниками відповідних деліберацій мають стати представники громадської думки ЄС (у тому числі і представники політичних еліт), обрані рівномірно випадковим чином з усіх країн-учасниць, належним чином поінформовані перед проведенням заходу, опитані на початку та в кінці консультації, керовані неупередженими модераторами. Акцентовано, що перспективи організації відповідного публічного простору стикаються з низкою проблем: ідентифікація громадськості ЄС, мовна, культурна, ідентифікаційна відмінності, демократичний дефіцит, вибір кандидатів та політик тощо. Зазначено, що існує кілька ключових напрямів, де ідея публічної сфери, задумана на національному рівні, має бути переусвідомлена на більш загальному транснаціональному рівні: переконання, що суверенна влада здійснюється в межах національних держав; розуміння економіки як такої, що територіально локалізована в межах національної держави; уявлення про те, що публічний діалог відбувається серед громадян, що проживають у межах однієї держави; передбачення єдиної спільної мови; інтенції до формування спільної літератури, культури та ідентичності; прагнення до спільної комунікаційної інфраструктури, що уможливить об'єднаний діалог. Виявлено, що імовірність реалізації мікрокосмічної стратегії може бути верифікована, на думку Дж. Фішкіна, шляхом запуску пілотного проекту.

Ключові слова: теорія деліберативної демократії; деліберація; публічне рішення; публічна сфера; мікрокосмічна стратегія; національна держава; вибірка

\section{Problems of deliberative practices in the European Union by James Fishkin}

\section{Kovalov A. V., Taras Shevchenko National University of Kyiv}

The article contains a comprehensive study attempt of the prospects of deliberative practices across the European Union, rather than individual member-states in the context of James Fiskin's democracy theory. It is proved that systematic use of a deliberative methodology for the improvement of democracy in the EU is possible only if a common public sphere is formed that can become the basis for making general public decisions on the problems of the European Union in the process of advisory consultations. It is emphasized that the prospects of organization of the corresponding political space face a number of problems: EU public identification, linguistic, cultural, identity differences, democratic deficit, choice of candidates and politics, etc. Moreover, it is noted that there are several key areas in which the idea of the public sphere, conceived at the national level, must be redefined at a more general transnational level: the belief that sovereign power is exercised within national states; understanding of the economy as being territorially localized within the national state; the notion that a public dialogue is taking place among citizens living within a single state; prediction of a single common language; the intention to form a common literature, culture and identity; the desire for a common communication infrastructure that enables a united dialogue. It is revealed that the probability of the implementation of the microcosmic strategy can be verified, according to J. Fishkin, by launching a pilot project. Microcosmic strategy involves the formation of a pan-European community that will be capable for representative dialogue through the borders of languages and nationalities. This is much more than an attempt to deepen public dialogue within the nation-state. The EU's microcosm enables dialogue in one place, during which all major outlooks of the mass public would be given the opportunity to be heard, including controversial ones.

Keywords: deliberative democracy theory; deliberation; public decision; public sphere; microcosmic strategy; national state; sample 


\title{
Проблемы делиберативных практик в Европейском Союзе по Джеймсу Фишкину
}

\author{
Ковалев А. В., Киевский национальный университет имени Тараса Шевченко
}

Предпринята попытка комплексного исследования перспектив делиберативных практик в масштабах Европейского Союза, а не отдельных государств-членов в контексте теории демократии Джеймса Фишкина. Доказано, что системное использование делиберативной методологии совершенствования демократии в ЕС возможно лишь при условии формирования общей публичной сферы, которая сможет стать фундаментом для разработки общих публичных решений по проблемам Европейского Союза в процессе совещательных консультирований. Акцентировано, что перспективы организации соответствующего публичного пространства сталкиваются с рядом проблем: идентификация общественности ЕС, языковое, культурное, идентификационное различия, демократический дефицит, выбор кандидатов и политик и тому подобное. Отмечено, что существует несколько ключевых направлений, где идея публичной сферы, задуманная на национальном уровне, должна быть переосмыслена на более общем транснациональном уровне: убеждение, что суверенная власть осуществляется в пределах национальных государств; понимание экономики как таковой, что территориально локализована в пределах национального государства; представление о том, что публичный диалог происходит среди граждан, проживающих в пределах одного государства; предвидение единого общего языка; интенции к формированию общей литературы, культуры и идентичности; стремление к общей коммуникационной инфраструктуре, которая позволит объединенный диалог. Обнаружено, что вероятность реализации микрокосмической стратегии может быть верифицирована, по мнению Дж. Фишкина, путем запуска пилотного проекта.

Ключевые слова: теория делиберативной демократии; делиберация; публичное решение; публичная сфера; микрокосмическая стратегия; национальное государство; выборка

Постановка проблеми у загальному вигляді та її зв'язок із важливими науковими та практичними завданнями.

Уучасна теорія демократії вирізняється новаторськими підходами, вираженими у численних концептах та моделях. Однією з таких новітніх спроб постає розроблена американським політологом Джеймсом Фішкіним теорія деліберативної демократії, яка передбачає активне використання у процесі вироблення публічних рішень дорадчих консультацій із представниками громадськості. Серед дослідників існує думка, що використання консультативних форм (зокрема референдумів) $\epsilon$ інструментом партисипаторної демократії [4, с. 28]. Проте, ідеї Дж. Фішкіна, певною мірою базуючись на положеннях партисипаторного підходу, мають інші аксіологічні пріоритети. Теоретичні розробки дослідника довели свою практичну значущість, насамперед, на муніципальному та загальнодержавному рівні (досвід західний демократій, КНР тощо) і мають значний потенціал у транснаціональній площині.

Аналіз останніх публікацій за проблематикою та визначення невирішених раніше частин загальної проблеми.

Окремі аспекти деліберативної політики досліджувалися такими науковцями, як С. Бенхабіб, Дж. Бессет, Р. Даль, Дж. Драйзек, Д. Дьюї, Ю. Габермас, Дж. Коен тощо. Специфіка прак- тичної імплементації деліберативного інструментарію на рівні окремих держав Європейського Союзу вивчалася Дж. Капелла, Е. Моравчиком, Л. Ніром, В. Прайсом, Н. Фрейзер і т. д. Однак, аспект перспектив деліберативних консультувань на загальному рівні $\mathrm{CC}$, а не його окремих держав-членів, особливо авторська візія Джеймса Фішкіна цього питання, $є$ мало дослідженими у науково-дослідній літературі.

Формулювання цілей (мети) статті.

Відтак, мета статті полягає у комплексному дослідженні умов імплементації деліберативних технік на рівні $\mathrm{CC}$, перспектив формування єдиного публічного простору $\mathrm{CC}$, а також перепон, які виникають на цьому шляху.

Виклад основних результатів та їх обгрунтування.

Демократичні дорадчі консультування у Свропейському Союзі на шляху практичної імплементації стикаються 3 низкою викликів, традиційних (загальних для деліберативних практик у будь-якій демократичній країні) та специфічних (властивих суто (С). Насамперед, спадає на думку так званий «демократичний дефіцит» - ізольованість діяльності політичних еліт від інтересів громадян. У той же час експерти зазначають, що «культурна політика $\mathrm{CC}$ формується за активної участі громадського сектора. Прийняттю важливих документів, таких як, наприклад, Зелена книга 2010 року стосовно творчих індустрій, передують гро- 
мадські консультації, збір коментарів від широкої громадськості, органів державної влади і структур громадянського суспільства, багатьох європейських організацій, що працюють в культурній сфері [1, с. 6-7]. Однак, у випадку Свропейського Союзу громада - це населення 28 країн-членів із притаманними виключно їм публічними дискурсами та власними політичними системами. Попри наявність Парламенту СС, його інтенції з вироблення політики можуть бути охарактеризовані як слабкі та малоефективні.

Отже, перша проблема - це ідентифікація громадськості, 3 якою можна проводити консультування в межах економічного та політичного союзу незалежних держав-учасниць. Джеймс Фішкін задається питанням, якою має бути логіка деліберативних консультувань у СС: спільна чи сепаратна у кожній державі? «Спільне консультування має перевагою об'єднаний розгляд різних цінностей, інтересів та перспектив в єдиному форумі, де можна вивчити та відповісти на конкуруючі аргументи. Окремі ж консультації знаходяться ближче до владних центрів, і кожна держава матиме бажання вирішувати самостійно» [6, с. 128]. Суверенність держав-членів схиляє відповідь у бік окремих консультації, натомість федеральний характер союзу з амбіціями на спільну публічну царину підштовхує до рішення на користь єдиного дискурсу.

Інша проблема криється в особливостях проведення деліберативних консультувань у Свропейському Союзі в контексті фундаментальної та повторюваної дилеми транснаціонального характеру, пов'язаної з вибором кандидатів та політик. Безпосереднє консультування 3 людьми 3 низьким рівнем поінформованості призводить до превалювання плебісцитної форми політики. Проте, консультування виключно 3 елітами постає недемократичним та відірваним від занепокоєнь громадян заходом. Якщо рішення лишається за партіями та парламентами, населення позбавлене можливості висловити свою згоду чи незгоду 3 приводу конкретного питання. Але якщо вирішення проблеми спрямовується безпосередньо на людей, тоді виникає небезпека того, що рішення буде прийняте на підставах, далеких від першорядних проблем $\mathrm{CC}$, про які громадськість може взагалі нічого не знати.

Враховуючи цей контекст, Джеймс Фішкін пропонує обрати третій (середній) шлях - деліберативний мікрокосм, але для цього має бути визначена публічна сфера $\mathrm{CC}$ - спільний громадський простір, в якому зможе сформуватися громадська думка та сприяти окресленню колективної волі.
Однак, така громадська думка має відповідати принаймні двом критеріям: бути вірогідною та послідовною. Де факто ж існує лише ослаблена версія того, що можна назвати громадською думкою ЄС. Певною мірою вона є сформованою щодо ключових проблем об'єднання у межах окремих національних держав: публічні сфери обговорення є сегментованими за національними та лінгвістичними кордонами, а також відповідними медіа-ринками. Безперечно, віртуальна дискусія відкриває можливості для часткового подолання проблеми, однак, мова все ще лишається перманентним бар'єром. Населення конкретної національної держави надає перевагу спілкуванню 3 співвітчизниками. Навіть на державному рівні проблеми СС мають низьку значимість та низькій рівень поінформованості мас. Вибори в Свропейському Союзі у науково-дослідний літературі часто кваліфікують як «вибори другого гатунку», побічний продукт національної політики [10].

Третя проблема стосується самої можливості спілкування, взаємного порозуміння. У ЄС нараховується 23 офіційні мови. Для реалізації мікрокосмічної версії загальноєвропейської публічної сфери необхідне використання спеціального технологічного інструментарію для подолання перепон лінгвістичного характеру. Відтак, дорадчі проекти ЄС наближаються до практичної реалізації у віртуальному форматі за використання апаратів синхронного перекладу з гарнітурами.

Четверта проблема пов'язана 3 унікальною природою $Є С$ як транснаціональної організаціï, яка поєднує в собі елементи федеративного устрою та автономних держав, які відрізняються договірними відносинами та специфікою координації таких сфер, як грошова політика, спільні кордони тощо. «Якщо громадські консультації повинні сприяти формуванню колективної волі, що таке відповідна громадськість, і які установи можуть розглядати їі результати? Хто поінформований і хто є адресатом будь-якої консультації? Хто є одержувачем результатів...?» [6, с. 129].

Однією зі стратегій громадських консультацій з питань ЄС, на думку Джеймса Фішкіна, може бути їхнє проведення на рівні національних держав 3 визначеною кількістю громадян та посадовцями, які можуть бути відповідальними за організацію даного заходу і систематизувати отримані результати. Історія СС пам'ятає численні референдуми та соціологічні опитування з питань об'єднання на рівні національних держав (Велика Британія, Данія тощо) [3]. Проте такі зусилля є замалими для формування загальноєвропейської ко- 
лективної волі. I нагальні проблеми $\mathrm{CC}$ не можуть бути адекватно розглянуті в межах кордонів окремих національних держав-членів. 3 одного боку, ЄC матиме більші перспективи з вирішення спільних проблем, якщо залишить їхнє розв'язання у межах відповідальності політичних еліт країн-учасниць, а не громадськості, оскільки консультації 3 необізнаними громадянами можуть бути небезпечними та безвідповідальними [8]. У той же час посилення демократичних норм, які стають все більш партисипаторними та прямими, в межах національних держав виглядає більш демократично за елітарні альтернативи. Відтак, виникає тяжіння до громадської консультації на рівні Європейського Союзу. Джеймс Фішкін переконаний, що занепокоєння нової Європи не перетиналися б із занепокоєннями старої Європи, а турботи Північної Європи з її високорозвинутими країнами добробуту не пересікалися б з проблемами країн Південної Європи, в яких питання соціального та пенсійного захисту є значно менш розвинутими. Однак, така деліберація радше б нагадувала «анклавне обговорення» 3 імовірною дезінформацією щодо інших країн та стереотипним ходом міркувань.

Б. Барбер вважає, що на даному етапі суспільного розвитку політична участь громадян відіграє роль певного механізму трансформації приватних інтересів у суспільні. У результаті відповідної трансформації має з'явитися публічна царина, в межах якої відбуватиметься перманентний публічний діалог між різними суб'єктами політичного процесу. На переконання ученого, насамперед, активні громадяни постають головними акторами публічного діалогу [5, с. 106].

Публічна сфера - це дорадча комунікативна система. Проте формування спільної колективної волі не схвалюється усіма теоріями демократій, приміром, елітарна або змагальна форми демократії не передбачають вироблення загальної волі народу. По суті, у такому випадку демократія перетворюється на боротьбу за голоси виборців 3 метою отримання владних повноважень однією політичною елітою у конкурентній боротьбі з іншою та їхньої легітимації. Таку демократію можна визначити як мінімалістичну. У той же час вона містить і певні позивні якості - прагне захищати права через конституціоналізм та судові рішення. Джеймс Фішкін зазначає, що така форма демократії підкреслює політичну рівність через конкурентні виборчі процеси та уникнення тиранії більшості через захист прав. Важливим досягненням $€$ забезпечення судових гарантій та мирний метод чергування еліт при владі. У відповідному кон- тексті теорія $є$ цілком задовільною, проте за більш амбітних претензій перетворюється на ілюзорну.

«Проте, заперечуючи значимість формування громадської волі, конкурентна демократія зберігає механізм демократії без душі» [6, с. 130]. Можливість прийняття публічного рішення, яка покликана «оживити» демократичний процес, зводиться виключно до змагальних зусиль отримати більшість голосів виборців і діяти від їхнього імені, але далеко не завжди в їхніх інтересах. Вибори, перемога в яких здобута шляхом маніпулювання чи обману неуважної громадськості, - це груба політична гра.

Партисипаторна теорія демократії, на думку вченого, також не робить формування колективної волі своєю метою. Вона акцентує першочергову увагу на тому, чи беруть участь люди у виборах та чи однаково підраховуються їхні голоси. Вимога до міркувань населення взагалі не ставиться. Однак, якби люди міркували та були добре поінформовані з приводу предмету голосування, це було б черговою перевагою виборчого процесу.

За елітарної деліберації громадська воля має непряме вираження через уповноважених представників. Еліти голосують за те, чого населення, на їхню думку, прагне. Це викривлена рефлексія загальної волі. Представники від народу уточнюють та розширюють волю людей, але передають iii через представницьку установу. У межах даної теоретичної настанови масове обговорення не передбачається і навіть може сприйматися як небезпечне. Прагнення до громадських консультувань видається утопічним, помилковим та безвідповідальним.

Це прагнення особливо оскаржується у контексті ЄС. Так, наприклад, Ендрю Моравчик вважає, що найбільше, на що можуть розраховувати деліберативні практики, - це серія більш розвинутих публічних сфер, сегментованих на національному рівні [9].

У той же час існують і прибічники деліберативної теорії демократії у СС, які переконані, що стратегія елітарної деліберації намагається обмежити застосування публічної сфери застарілою Вестфальською системою окремих держав-націй, кордони яких вже не можуть запропонувати ефективних політичних чи економічних рішень, а також об'єктивно відображати рух товарів та людського ресурсу, специфіку комунікаційних процесів у все більш мобільному світі ідей та людей. Якщо принципи та ідеали демократії мають значення, ідея транснаціональної публічної сфери має бути адаптованою до об’єднаної Європи. 
Можна виділити кілька ключових напрямів, де ідея публічної сфери, задумана на національному рівні, має бути переусвідомлена на більш загальному транснаціональному рівні. Оригінальне габермасівське поняття публічної сфери, в межах якої громадська думка може бути відфільтрована до якості колективної волі для прийняття певного публічного рішення, було задумане для застосування у національній державі. I хоча Ю. Габермас визнавав труднощі застосування цього поняття у транснаціональному контексті, вони лише підсилюють нагальність інституційного експерименту 3 вирішення проблеми [7].

В іншому випадку, розширюючи власні повноваження Європейський Союз зазіхає на повноваження країн-членів, чим підсилює дефіцит демократії як такої, адже відсутня належна легітимація таких дій. Якщо ЄС залишиться повністю незалежним від конституційних нововведень, небезпека полягатиме у тому, що цей дефіцит зростатиме день у день, оскільки економічна та соціальна динаміка навіть в межах існуючих інституційних структур закріплюватиме «ерозію» національних держав через європейське право. Необхідні нові транснаціональні форми легітимації, але вони стикаються 3 труднощами нерозвиненої загальноєвропейської публічної сфери та фрагментації суспільної свідомості, залишаючи нас з «майбутнім ілюзії минулого», відповідно до якої суспільства можуть визначати власну долю через політичну волю та свідомість [7].

Отже, серед базових порушень публічної сфери, які виразно проявляються в масштабах $\mathcal{C}$, можна виділити наступні:

- переконання, що суверенна влада здійснюється в межах національних держав. Оскільки ЄС набуває все більшої влади через укладання договорів та бюрократичні зазіхання, рішення приймаються в Брюсселі, а не в окремих державах;

- розуміння економіки як такої, що територіально локалізована в межах національної держави. У глобалізованому світі це припущення $\epsilon$ менш релевантним, і практична економіка $\mathrm{CC}$ свідчить на користь того, що все більше рішень у цій царині приймається не на рівні детермінації окремої держави, а в масштабах усього $С \mathrm{C}$, зазвичай централізованими інституціями Сврозони;

- $\quad$ уявлення про те, що публічний діалог відбувається серед громадян, що проживають в межах однієї держави. Свобода пересування як право, закріплене в СC, i, відповідно, відсутність жорсткої прив'язки до громадянства подолали кордони традиційних національних держав;
- передбачення єдиної спільної мови. Існування 23 офіційних мов не створює належних підстав для взаємного порозуміння у ході єдиного діалогу. Хоча деякі держави у складі СС взяли мовну багатоманітність за основу демократичного розвитку, зокрема, Швейцарія, в якій лінгвістична різноманітність стала ключовим аспектом ідентичності, існує велика відмінність між 4 і 23 мовами;

- інтенції до формування спільної літератури, культури та ідентичності. Де факто існує велика кількість літератур і слабке визнання поділюваних культури та ідентичності;

- прагнення до спільної комунікаційної інфраструктури, що уможливить об'єднаний діалог. Лінгвістичні відмінності та національне правове регулювання діяльності засобів масової інформації розщеплюють таку можливість.

Усі ці чинники перманентно порушуються у межах держав-націй. А загальноєвропейський контекст робить цей виклик експліцитним по відношенню до всіх 28 країн-членів ЄС. Властивий об'єднанню демократичний дефіцит свідчить про розрив між елітами, які можуть брати чи не брати участь у громадських консультуваннях, і населенням, яке, скоріше за все, мінімально або взагалі необізнане з приводу актуальних проблем ЄС.

Деліберативні еліти без публічної сфери, яка підтримує та забезпечує свій внесок до їхнього рішення, підриває медісонівську елітарну деліберативну модель. Як учасники таких обговорень можуть рафінувати позиції громади, якщо переважна більшість населення незнайома, і немає навіть натяку на те, яким чином на масовому рівні громадськості відбуватиметься вираз думок у різних країнах, на різних мовах та $з$ різними уявленнями про актуальні проблеми. Еліти за таких умов навіть при добросовісних спробах обмірковувань зможуть прийти до висновку, що вони «з різних планет» та надто відірвані від реальної публічної сфери, інтереси якої вони мають відстоювати. Без загальноєвропейської публічної сфери елітарній демократії бракуватиме будь-яких підстав для формування колективної волі. Те саме стосується й партисипаторного підходу. Сдиним прийнятним шляхом розв'язання цієї дилеми, на думку Джеймса Фішкіна, постає мікрокосмічна стратегія, яка застосовуватиметься до всього простору СС та базуватиметься на залученні громадськості до дорадчої демократії.

Ця стратегія передбачає формування загальноєвропейської спільноти, яка буде спроможною до репрезентативного діалогу крізь кордони мов та національностей. Це значно суттєвіше за спробу поглибити публічний діалог в межах держави-на- 
ції. Мікрокосм ЄС уможливлює діалог в одному місці, під час якого усі основні перспективи масової громадськості отримали б нагоду бути висловленими, почутими, враховуючи суперечливі.

«Становлення Свропейського Союзу як колективного утворення органічно передбачає формування європейської ідентичності в межах єдиного соціокультурного простору. Усвідомлення себе «європейцем» - навіть не так у ментальному, як у політичному сенсі - це шлях до справжнього згуртування народів і держав, що творять європейську спільноту» [2, с. 72].

Яким же чином організаційно усі думки масової громадськості можуть бути зведені до обговорення у відносно малому органі в одному місці одночасно? Репрезентативність органу свідчить про те, що висвітлюються усі громадські позиції, а їхній збір в одній локації гарантує взаємодію, а не паралельне буття. При нагоді організаторам стануть і сучасні інформаційно-комунікаційні технології, які допоможуть перетнути державні кордони і сприяти формуванню єдиного публічного простору ЄС. Попри усі складнощі та перепони, автор деліберативної концепції демократії, наголошує на необхідності запуску принаймні пілотної версії вище описаного мікрокосму, адже цього вимагає сучасний стан загальних публічних проблем Європейського Союзу.

\section{Висновки та перспективи подальших до- сліджень.}

Отже, повномірне використання деліберативної методології рафінування демократії в СС можливе лише за умови кристалізації єдиної публічної сфери, яка зможе стати ареною вироблення спільних публічних рішень стосовно проблем Свропейського Союзу у ході дорадчих консультувань. Учасниками відповідних деліберацій мають стати представники громадянського суспільства (у тому числі і представники політичних еліт), обрані рівномірно випадковим чином з усіх країн-учасниць, належним чином поінформовані перед проведенням заходу, опитані на початку та в кінці консультації, керовані неупередженими модераторами. На жаль, перспективи формування відповідного політичного простору стикаються 3 низкою проблем: мовна, культурна, ідентифікаційна відмінності, демократичний дефіцит тощо. Імовірність реалізації мікрокосмічної стратегії може бути верифікована, на думку Дж. Фішкіна, шляхом запуску пілотного проекту. Подальші вектори дослідження проблеми можуть бути спрямовані у бік аналізу позитивних результатів деліберацій у масштабах $€ C$, а також можливостей імплементації дорадчих консультувань в Україні в контексті євроінтеграційних процесів.

\section{БІБІЛІОГРАФІЧНІ ПОСИЛАННЯ}

1. Здіорук С. I. Культурна політика України: національна модель у європейському контексті / C. I. Здіорук, О. М. Литвиненко, О. П. Розумна. - Режим доступу: http://www.niss.gov.ua/content/articles/files/Kul\%5C_tura20126090f.pdf

2. Козловець М. А. Європейська ідентичність: уніфікація чи «єдність в розмаїтті»? / М. А. Козловець. - Режим доступу: http://www.zgia.zp.ua/gazeta/VISNIK 37_7.pdf

3. Милосердна I. М. Законодавче закріплення та функціонування інституту референдуму: світовий досвід /

I. М. Милосердна. - Режим доступу: http://dspace.onua.edu.ua/bitstream/handle/11300/290/Miloserdina\%20 Zakonadav\%20zakr2.pdf?sequence $=1$ \&isAllowed $=\mathrm{y}$

4. Чебаненко О. Д. Референдуми в Свропейському Союзі / О. Д. Чебаненко, О. Ю. Грищук, Н. В. Колодяжна, А. Євгеньєва; за ред. Д.С. Ковриженка. - Київ: ФАДА, ЛТД, 2007. - 186 с.

5. Barber B. Strong Democracy: Participatory Politics for a New Age / B. Barber. - Berkeley: University of California Press, 2003. $-320 \mathrm{p}$.

6. Fishkin J. When the People Speak, Deliberative Democracy and Public Consultation / J. Fishkin. - Oxford: Oxford University Press, 2009. - 183 p.

7. Habermas J. Remarks on Dieter Grimm’s «Does Europe Need a Constitution?» / J. Habermas // European Law Journal. - 1995. - Vol. 1. - № 3. - P. 303-307.

8. Moravscik A. Another Angle / A. Moravscik. - Retrieved from: http://www.princeton.edu/ amoravcs/library/E!Sharp.pdf 9. Moravscik A. What Can We Learn from the Collapse of the European Constitutional Project? / A. Moravscik. Retrieved from: http://www.princeton.edu/ amoraves/library/PVS04.pdf

10. Schmitt H. The European Parliament Election of June 2004: Still Second Order / H. Schmitt // West European Politics. - 2005. - Vol. 28. - № 3. - P. 650-679. 


\section{REFERENCES}

1. Zdioruk, S.I., Lytvynenko, O.M., \& Rozumna, O.P. (2012). Kulturna polityka Ukrainy: natsionalna model u yevropeiskomu konteksti [Cultural Policy of Ukraine: National Model in European Context]. Retrieved from: http:// www.niss.gov.ua/content/articles/files/Kul\%5C tura2012-6090f.pdf [in Ukrainian].

2. Kozlovets, M.A. (2009). Yevropeiska identychnist: unifikatsiia chy «iednist v rozmaitti»? [European identity: unification or «unity in diversity»?]. Retrieved from: <http://www.zgia.zp.ua/gazeta/VISNIK_37_7.pdf> [in Ukrainian].

3. Myloserdna, I.M. (2014). Zakonodavche zakriplennia ta funktsionuvannia instytutu referendumu: svitovyi dosvid [Legislative consolidation and functioning of the referendum institute: world experience]. Retrieved from: http://dspace.onua.edu.ua/ bitstream/handle/11300/290/Miloserdina\%20Zakonadav\%20zakr2.pdf?sequence=1\&isAllowed=y [in Ukrainian].

4. Chebanenko, O.D., Hryshchuk, O.Yu., Kolodiazhna, N.V., \& Yevhenieva, A. (2007). Referendumy v Yevropeiskomu Soiuzi [Referendums in the European Union]. D. S. Kovryzhenko (ed.). Kyiv: FADA, LTD [in Ukrainian].

5. Barber, B. (2003). Strong Democracy: Participatory Politics for a New Age. Berkeley: University of California Press. 6. Fishkin, J. (2009). When the People Speak, Deliberative Democracy and Public Consultation. Oxford: Oxford University Press

7. Habermas, J. (1995). Remarks on Dieter Grimm’s «Does Europe Need a Constitution?» European Law Journal, 1 (3), $303-307$. 8. Moravscik, A. (2008). Another Angle. Retrieved from: <http://www.princeton.edu/ amoravcs/library/E!Sharp.pdf >.

9. Moravscik, A. (2006). What Can We Learn from the Collapse of the European Constitutional Project? Retrieved from: $<\mathrm{http}$ ://www.princeton.edu/ amoravcs/library/PVS04.pdf $>$.

10. Schmitt, H. (2005). The European Parliament Election of June 2004: Still Second Order. West European Politics, 28 (3), 650-679.

\section{Ковальов Андрій Вікторович}

Аспірант кафедри державного управління

Київський національний університет імені Тараса Шевченка

01601, Київ, вул. Володимирська, 60

\section{Kovalov Andrii}

PhD Student of Public Administration chair

Taras Shevchenko National University of Kyiv

60, Volodymyrska str., Kyiv, 01601, Ukraine,

ORCID: 0000-0003-1081-3024_Email: Kovalyov_A_V@ukr.net

Цитування: Ковальов А. В. Проблеми деліберативних практик у Європейському Союзі за Джеймсом Фішкіним / А. В. Ковальов // Науково-теоретичний альманах «Грані». - 2018. - Т. 21. - № 6. - С. 59-65.

Citation: Kovalov, A.V. (2018). Problemy deliberatyvnykh praktyk u Yevropeiskomu Soiuzi za Dzheimsom Fishkinym [Problems of deliberative practices in the European Union by James Fishkin]. Scientific and theoretical almanac «Grani», 21(6), 59-65. 